Scientia Marina 71(2)

June 2007, 213-222, Barcelona (Spain)

ISSN: 0214-8358

\title{
Comparative study on the reproductive biology of Torpedo torpedo (Linnaeus, 1758) and T. marmorata (Risso, 1810) in the central Mediterranean Sea
}

\author{
IVAN CONSALVO, UMBERTO SCACCO, MICHELE ROMANELLI \\ and MARINO VACCHI
}

Istituto Centrale per la Ricerca scientifica e tecnologica Applicata al Mare, Via di Casalotti 300, 00166 Roma, Italy.

E-mail: ivcons@libero.it

\begin{abstract}
SUMMARY: The reproductive biology of Torpedo torpedo $(\mathrm{n}=535)$ and Torpedo marmorata $(\mathrm{n}=385)$, collected in coastal waters of Latium (central Mediterranean Sea, Italy) between September 2000 and October 2001, was studied and compared. Males and females reached a maximum length of 445 and $477 \mathrm{~mm}$ TL in T. torpedo and 364 and $553 \mathrm{~mm}$ TL in T. marmorata. Males and females of $T$. torpedo reached length at sexual maturity $\left(\mathrm{TL}_{50 \%}\right)$ at similar sizes $(249 \mathrm{~mm} \mathrm{TL}$ and $258 \mathrm{~mm}$ TL respectively) whereas $\mathrm{TL}_{50 \%}$ in females of $T$. marmorata was greater than that of males (312 and $251 \mathrm{~mm}$ TL respectively). Analysis of the gonadosomatic index (GSI) and maximum oocyte diameter (MOD) in mature females suggested that gestation lasted about 6 months in T. torpedo and 9 to 10 months in T. marmorata. Fecundity was positively correlated with length in both species and, comparing ovarian and uterine fecundity, $T$. torpedo had a greater reproductive potential than $T$. marmorata. Size at birth of $T$. torpedo was smaller than that of $T$. marmorata and embryos of the latter showed a higher rate of mass increment with size than those of $T$. torpedo.
\end{abstract}

Keywords: elasmobranchs, rajiformes, reproduction, life-cycle, central Mediterranean.

RESUMEN: ESTUDIO COMPARATIVO EN BIOLOGÍA REPRODUCTIVA DE LAS ESPECIES SIMPÁTRICAS TORPEDO TORPEDO (LINNAEUS, 1758) Y TORPEDO MARMORATA (RISSO, 1810) EN EL MAR MEDITERRÁNEO CENTRAL. - La biología reproductiva de las especies Torpedo torpedo $(\mathrm{n}=535)$ y Torpedo marmorata $(\mathrm{n}=385)$, recolectadas en las aguas costeras del Mar Mediterráneo central italiano, desde septiembre de 2000 hasta octubre de 2001, ha sido estudiada y comparada. Los machos y las hembras alcanzaron la longitud máxima de 445 y $477 \mathrm{~mm}$ TL en $T$. torpedo y de 364 y $553 \mathrm{~mm}$ TL en $T$. marmorata. Las hembras de T. marmorata resultarón ser mayores que las de T. torpedo. El resultado contrario fue obtenido en los machos. Machos y hembras de $T$. torpedo alcanzaron la talla de madurez sexual $\left(\mathrm{TL}_{50 \%}\right)$ con tallas similares $(249 \mathrm{~mm}$ TL y $258 \mathrm{~mm}$ TL respectivamente), mientras que la $\mathrm{TL}_{50 \%}$ de las hembras de $T$. marmorata resultó ser mayor que de la de los machos (312 y 251 $\mathrm{mm}$ TL respectivamente). Las variaciones del índice gonadosomático (GSI) y del diámetro máximo de los ovocitos (MOD) en las hembras maduras, sugirieron un período de gestación de seis meses en T. torpedo y nueve o diez meses en $T$. marmorata. La fecundidad tendió a aumentar proporcionalmente con la longitud. La comparación entre la fecundidad ovarica y uterina de las especies estudiadas, indicó que $T$. torpedo tenía un mayor potencial reproductivo que T. marmorata. La talla al nacer de $T$. torpedo resultó ser menor que en $T$. marmorata y los embriones de esta especie mostraran un crecimiento más rápido respecto a los embriones de $T$. torpedo.

Palabras clave: elasmobranquios, rajiformes, reproducción, ciclo vital, Mediterraneo central.

\section{INTRODUCTION}

Electric rays (Elasmobranchia: Torpedinidae) are cartilaginous fishes present in the Mediterranean Sea with four species (Bigelow and
Schroeder, 1953; Tortonese, 1956; Serena, 2005). Torpedo torpedo (Linnaeus, 1758) is an AtlanticMediterranean species (Quignard and Tomasini, 2000), mostly distributed along the Mediterranean eastern coasts, on soft bottoms at up to $160 \mathrm{~m}$ depth 
(Tortonese, 1956; Fischer et al., 1987). Torpedo marmorata (Risso, 1810) is distributed in the eastern Atlantic from Brittany to South Africa (Bini, 1967) and in the whole Mediterranean Sea (Stehmann and Bürkel, 1984), being more abundant on soft bottoms alongside its western coasts (Capapé, 1979), from the surface to depths of about 300 metres, occasionally 550 metres (Fischer et al., 1987). The migratory (Sthemann and Bürkel, 1984) Torpedo nobiliana (Bonaparte, 1835) is the rarest species and is only occasionally caught along the Mediterranean coasts. Torpedo sinuspersici is a Lessepsian species recently reported in the Mediterranean in inshore waters over sandy bottoms, down to a depth of $200 \mathrm{~m}$ (Serena, 2005).

Several recent studies have shown that the abundance of most species of elasmobranchs in the Mediterranean Sea has been sharply decreasing over the last few decades (Aldebert, 1997; Bertrand et al., 2000; Hemida et al., 2000; Vacchi and Notarbartolo di Sciara, 2000; Soldo, 2003), mainly as a consequence of high fishing pressure and their high sensitivity, due to their large size, late maturity and low fecundity (Walker and Hyslop, 1998). In the central Mediterranean Sea electric rays are commonly caught by commercial trawling as by-catch and usually discarded at sea, so data on catches of these species are largely unknown. Information on the reproductive biology of T. marmorata and T. torpedo is available for Tunisia (Quignard and Capapé, 1974; Capapé, 1979; Ennajar et al., 2002), the Atlantic coast of France, (Mellinger, 1971) and Egyptian Mediterranean waters (Abdel-Aziz, 1994). In the central Mediterranean Sea, studies on the reproductive biology of these species mostly concentrate on histochemical observations of the morphology and physiology of the female reproductive tract (Ranzi, 1932; Chieffi, 1961; Uva and Tagliaferro, 1968; Uva, 1971). Lo Bianco (1909) studied the fecundity of a few pregnant females of both species in the southern Tyrrhenian Sea. However, there is little up-to-date information on the reproductive biology of Torpedo spp. in the central Mediterranean Sea. Hence, the aim of this study is to increase knowledge of the length at first maturity, reproductive period and fecundity of $T$. marmorata and $T$. torpedo in the central Mediterranean Sea. In addition, it compares the reproductive biology of two out of four species of the genus Torpedo living in the Mediterranean Sea.

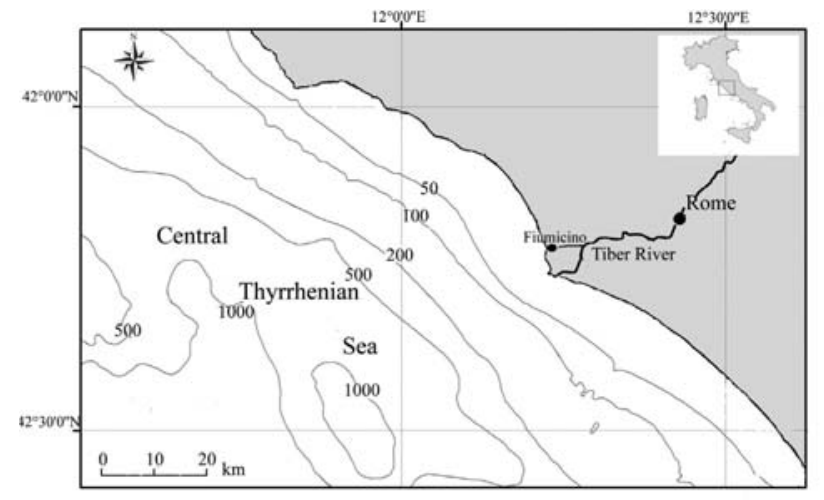

Fig. 1. - Map of trawl fishing grounds of Fiumicino landing harbour.

\section{MATERIALS AND METHODS}

Samples of the common torpedo T. torpedo $(\mathrm{n}=$ 535) and marbled electric ray T. marmorata $(\mathrm{n}=$ 385) were collected monthly from September 2000 to October 2001 (Table 1) at the landing site of Fiumicino harbour. Samples were obtained from catches of bottom trawlers (with a trawl net of 40 $\mathrm{mm}$ mesh diameter) operating on soft bottoms of the western coasts of Latium, from the coast down to $600 \mathrm{~m}$ depth, where the two studied species are particularly abundant (Fig. 1). The specimens obtained were representative samples of populations inhabiting the area, in relation to their known bathymetrical distribution (see introduction) and seasonality of reproductive cycle. Sex ratio (male/female) was calculated for three length groups (124 mm width) chosen according to maturity stages (I: immature, II: maturing, III; mature) and for the whole sample in the embryo population. Fishes were sexed and measured: total length (TL), total and eviscerated weight (TW, EW) were measured to the nearest millimetre and centigram respectively (Bass et al.,

TABLE 1. - Monthly samples of T. torpedo and T. marmorata.

\begin{tabular}{lcccc}
\hline \multirow{2}{*}{ Month } & \multicolumn{2}{c}{ T. torpedo } & \multicolumn{2}{c}{ T. marmorata } \\
& males & females & males & Females \\
\hline September 2000 & 5 & $/$ & 4 & 12 \\
October 2000 & $/$ & $/$ & 1 & 2 \\
November 2000 & 31 & 60 & 17 & 19 \\
December 2000 & 9 & 8 & 39 & 11 \\
January 2001 & 7 & 43 & 12 & 13 \\
February 2001 & 21 & 46 & 5 & 5 \\
March 2001 & 18 & 36 & 4 & 12 \\
April 2001 & 6 & 6 & 7 & 8 \\
May 2001 & 1 & 3 & 25 & 31 \\
June 2001 & 21 & 8 & 19 & 11 \\
July 2001 & 44 & 37 & 26 & 29 \\
August 2001 & 28 & 19 & 19 & 25 \\
September 2001 & 6 & 6 & 4 & 1 \\
October 2001 & 33 & 33 & 11 & 13 \\
& & & & \\
\hline
\end{tabular}


1973). Maturity stages were determined by macroscopic study of reproductive organs following a scale proposed by Stehmann (2002) and modified for these two species as follows:

- Active and/or copulating males were classified as mature.

- The "differentiating" developing stage was included in the "early pregnant" stage, whereas the "expecting" developing stage was pooled with the "late pregnant" stage because the presence of embryos in uteri always excluded the occurrence of unsegmented ova in Torpedo spp. females (Ranzi, 1932).

- The post-pregnant stage was added in order to describe the occurrence of females that were still widened over their full length but had empty uteri and ovaries empty or with small oocytes in initial vitellogenesis.

Testes and ovaries were weighed to $0.001 \mathrm{~g}$; maximum oocyte diameter (MOD) was measured to $1 \mathrm{~mm}$; clasper length was taken from the back end of the cloacal slit to the tip of the claspers. Gonadosomatic index (GSI) was calculated as $(\mathrm{GW} / \mathrm{EW}) \times 100$. Only GSI and MOD values of mature, early, late and post-pregnant females were considered in order to define the spawning season. Seasonal and monthly (or bi-monthly in the case of T. marmorata) data for GSI and MOD were represented as mean values. The number of ripe oocytes was counted in ovaries of all mature females and the number of segmented ova and/or embryos was recorded in uteri of pregnant females. Ovarian and uterine fecundity was defined as the number of oocytes and embryos or segmented ova, respectively. Developed embryos (T. torpedo 83 and T. marmorata 185 , respectively) were weighed without their yolk sac (EW) and measured to the nearest centigram and millimetre (TL). Linear regression analysis was applied to estimate EW-TL relationships. The analysis was carried out on natural logtransformed EW and TL data. A t-test was used to check for allometry (if slopes were significantly different from 3). Student's t-test was performed in order to estimate differences in the length-weight regression slope (Zar, 1996) among sexes within (male $v s$. female) and between species (female $v s$. female and male $v s$. male).

Linear regression analysis was also used to estimate variation of ovarian and uterine fecundity with length. Since fecundity was expressed by counts, a natural log-transformation of dependent variables was needed. Differences in the slope of length-ovar- ian and uterine fecundity relationships between females were tested by a Student's t-test. When slopes resulted similar (size effect on the dependent variable is not significantly different between species), a t-test was further used to check for differences in mean values. ANOVA was used to evaluate differences in mean GSI among seasons for both sexes. When significant, the LSD test was used as a post-hoc. Size at first maturity $\left(\mathrm{TL}_{50 \%}\right)$ was estimated using the following logistic model: frequency

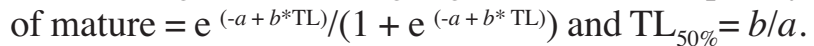
Loss function and estimation methods were Maximum Likelihood (Fisher, 1922) and Rosembrok-Quasi Newton (Hooke and Jeeves, 1961; Fletcher and Reeves, 1964), respectively. Differences from sex ratio 1:1 were checked by chisquare test on a $2 \times 3$ contingency table (males and females; length groups: $\mathrm{I}=96-220, \mathrm{II}=221-340$ and III $>341 \mathrm{~mm}$ ). Embryo sex ratio was checked by a simple chi-square test. All analyses were performed using STATISTICA 6.0 software.

\section{RESULTS}

The frequency distribution of sexes showed that females attained larger sizes than males in both species. This difference was less evident in T. torpedo (Fig. 2a), where the largest female measured $477 \mathrm{~mm}$ TL whereas the largest male measured $445 \mathrm{~mm}$ TL. Conversely, in T. marmorata (Fig. 2b) males were conspicuously shorter than females, the largest male and female measuring 364 and $553 \mathrm{~mm}$ TL, respectively.

Sex ratio did not differ among size groups $\left(\chi^{2}\right.$, d.f. $=2, \mathrm{P}>0.05)$ in T. torpedo, whereas it varied in $T$. marmorata $\left(\chi^{2}\right.$, d.f. $\left.=2, \mathrm{P}<0.001\right)$ : in the first and second size group, males exceeded females, and vice versa in the third one. Embryo sex ratio was not significantly different from $1: 1$, being $1.10\left(\chi^{2}\right.$, d.f. $=1, \mathrm{P}>0.05)$ and $0.80\left(\chi^{2}\right.$, d.f. $\left.=1, \mathrm{P}>0.05\right)$ in $T$. torpedo and T. marmorata, respectively.

Fitted TL-EW equations (Fig. 3a, b) were significant in both $T$. torpedo (males: F- test, d.f. $=1$ and 228, $\mathrm{P}<0.001$; females: F- test, d.f. $=1$ and 308, $\mathrm{P}<0.001$ ) and T. marmorata (males: F- test, d.f. $=1$ and 181, $\mathrm{P}<0.001$; females: F- test, d.f. $=1$ and 197 , $\mathrm{P}<0.001)$. A negative allometry was found in all cases (T. torpedo: males, t-test d.f. $=364, \mathrm{P}<0.001$; females, t-test d.f. $=620, \mathrm{P}<0.001 ;$ T. marmorata: males, t-test d.f. $=458, \mathrm{P}<0.001$; females, t-test 


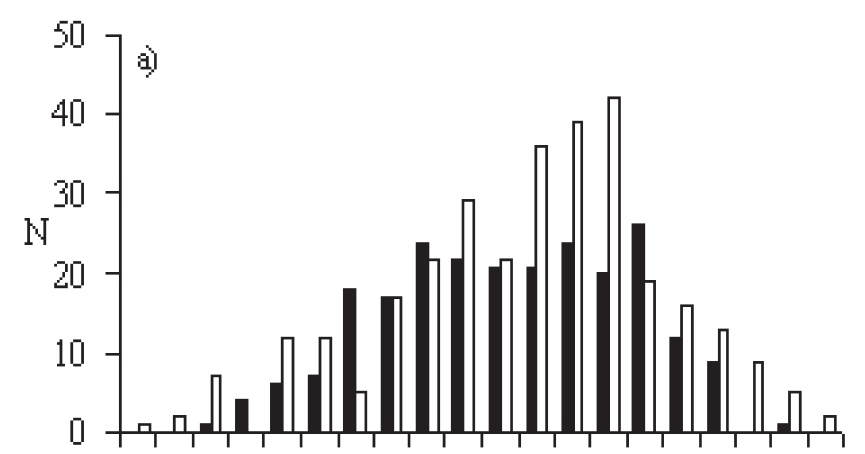

80120160200240280320360400440 Length classes (mm)

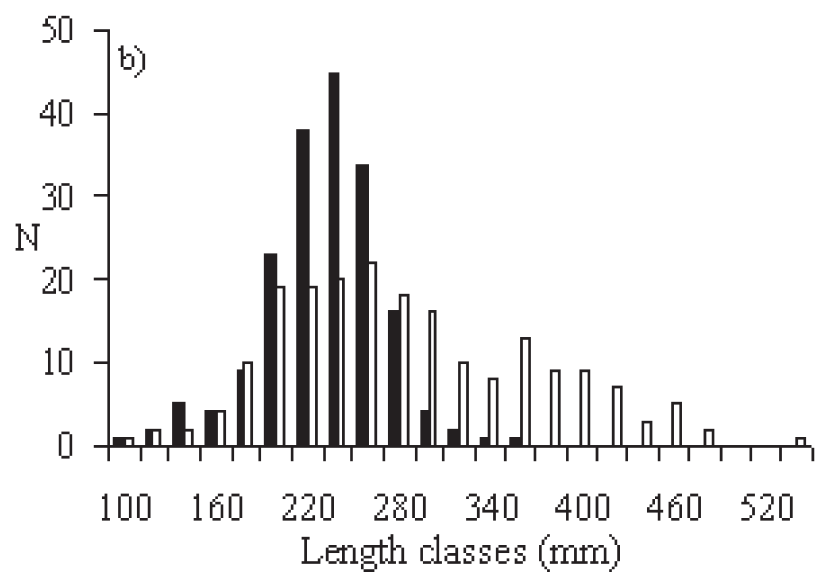

FIG. 2. - Size-frequency distribution by sex ( $\square$, females and $\boldsymbol{\square}$, males) computed by 20 mm width length classes in $T$. torpedo (a) and T. marmorata (b).
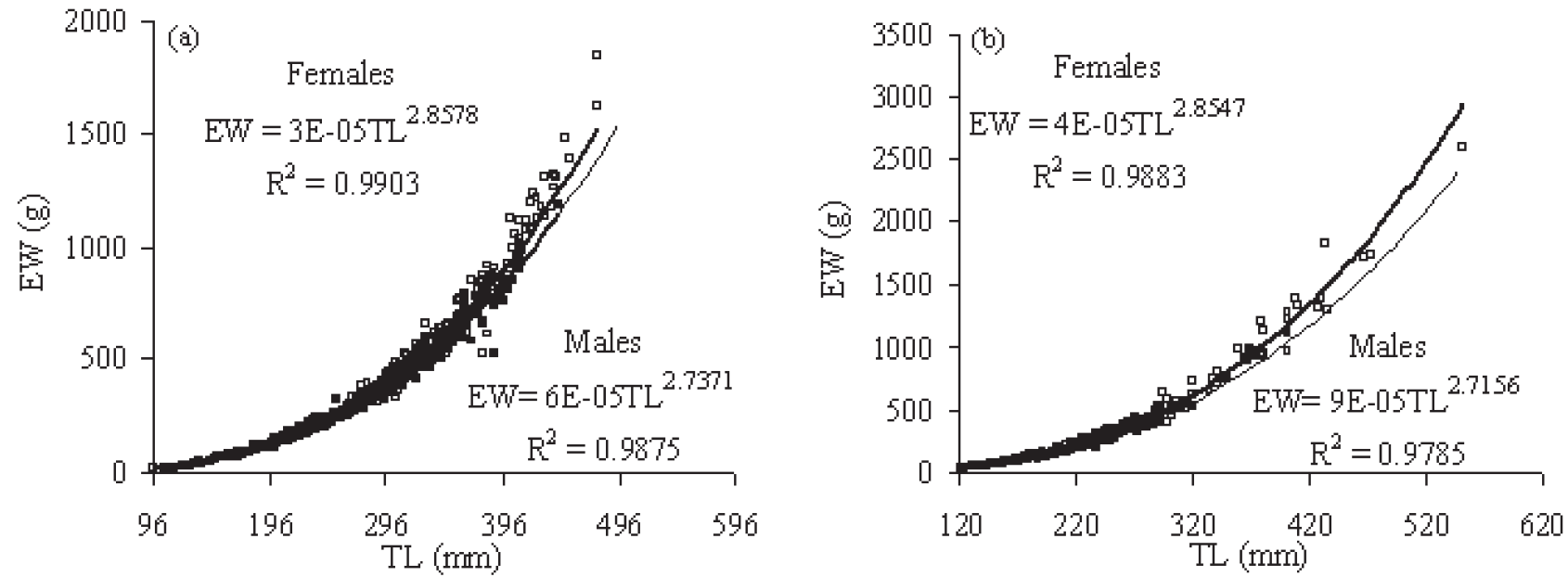

FIG. 3. - Relationships between eviscerated weight and total length in females ( $\square$ ) and males ( $\square$ ) of T. torpedo (a) and T. marmorata (b).

d.f. $=396, P<0.001)$. The slope of the fitted linearised TL-EW equations was significantly higher in females than in males in both $T$. torpedo (Student's t-test for homogeneity of slope: d.f. $=536, \mathrm{P}<0.001$ ) and T. marmorata (Student's ttest for homogeneity of slope: d.f.=378, $\mathrm{P}<0.001$ ). Conversely, the regression slope was similar in the comparison between females (Student's t-test for homogeneity of slope: d.f. $=506, P=0.79)$; since the effect of size was similar between females, mean eviscerated weight was further compared, resulting significantly higher (t-test: d.f. $=508$, $\mathrm{P}<0.01)$ in T. marmorata $(597.6 \mathrm{~g})$ than in T. torpedo $(485.3 \mathrm{~g})$.

In the comparison between males the allometric coefficient was similar (Student's t-test for homogeneity of slope: $\mathrm{d} . \mathrm{f}=409, \mathrm{P}>0.05$ ); therefore, mean eviscerated weight was significantly higher in $T$. torpedo (406.8 g) than in T. marmorata (266.2 g) (ttest: d.f. $=508, \mathrm{P}<0.01)$.
In $T$. torpedo the smallest mature and pregnant females had a TL of 235 and $275 \mathrm{~mm}$, respectively. Length at first maturity was estimated at 258 $\operatorname{mm} \operatorname{TL}\left(\chi^{2}\right.$, d.f. $\left.=1, \mathrm{P}<0.001\right)$. The smallest mature male had a TL of $227 \mathrm{~mm}$ and the largest immature one had a TL of $265 \mathrm{~mm}$. Male size at first maturity was $249 \mathrm{~mm}$ TL $\left(\chi^{2}\right.$, d.f. $\left.=1, \mathrm{P}<0.001\right)$. In $T$. marmorata, the smallest mature and pregnant females had a TL of 267 and $295 \mathrm{~mm}$, respectively. The size at first maturity was $312 \mathrm{~mm}$ TL $\left(\chi^{2}\right.$, d.f. $=1, P<0.001)$. The smallest mature male had a TL of 231 and the largest immature one had a TL of $275 \mathrm{~mm}$. Fifty per cent of males were mature at $251 \mathrm{~mm}$ TL $\left(\chi^{2}\right.$, d.f. $\left.=1, P<0.001\right)$. Mean female values of GSI increased after the length at first maturity in both species (Table 2), attaining values ranging between 4.1 and $10.3 \%$ in T. torpedo and between 1.1 and $9 \%$ in T. marmorata. Also, in males of both species, mean GSI increased after size at first maturity, differing from females for 
Table 2. - Variation of mean ( \pm S.D.) gonadosomatic index (GSI) in females and males of T. torpedo and T. marmorata according to size classes.

\begin{tabular}{|c|c|c|c|c|c|c|c|c|}
\hline \multirow[b]{2}{*}{$\begin{array}{l}\text { Length classes } \\
(\mathrm{mm})\end{array}$} & \multicolumn{4}{|c|}{ females } & \multicolumn{4}{|c|}{ males } \\
\hline & $\begin{array}{c}\text { T. torpedo } \\
\text { GSI }(\%)\end{array}$ & $\mathrm{n}$ & $\begin{array}{l}\text { T. marmorata } \\
\text { GSI }(\%)\end{array}$ & $\mathrm{n}$ & $\begin{array}{c}\text { T. torpedo } \\
\text { GSI (\%) }\end{array}$ & $\mathrm{n}$ & $\begin{array}{l}\text { T. marmorata } \\
\text { GSI }(\%)\end{array}$ & $\mathrm{n}$ \\
\hline 120 & $0.12 \pm 0.02$ & 7 & $0.09 \pm 0.01$ & 4 & - & & $0.10 \pm 0.09$ & 3 \\
\hline 140 & - & & $0.05 \pm 0$ & 1 & $0.08 \pm 0.01$ & 5 & $0.07 \pm 0.008$ & 5 \\
\hline 160 & $0.09 \pm 0.02$ & 12 & $0.07 \pm 0.02$ & 5 & $0.09 \pm 0.02$ & 5 & $0.08 \pm 0.009$ & 5 \\
\hline 180 & $0.10 \pm 0.03$ & 13 & $0.07 \pm 0.01$ & 9 & $0.008 \pm 0.001$ & 9 & $0.11 \pm 0.007$ & 9 \\
\hline 200 & $0.10 \pm 0.06$ & 5 & $0.05 \pm 0.007$ & 16 & $0.09 \pm 0.03$ & 19 & $0.15 \pm 0.009$ & 21 \\
\hline 220 & $0.20 \pm 0.17$ & 21 & $0.09 \pm 0.05$ & 22 & $0.10 \pm 0.07$ & 14 & $0.25 \pm 0.009$ & 39 \\
\hline 240 & $0.48 \pm 0.63$ & 20 & $0.10 \pm 0.06$ & 20 & $0.13 \pm 0.11$ & 24 & $0.31 \pm 0.10$ & 50 \\
\hline 260 & $4.12 \pm 2.5$ & 12 & $0.14 \pm 0.03$ & 16 & $0.20 \pm 0.14$ & 22 & $0.29 \pm 0.09$ & 28 \\
\hline 280 & $6.59 \pm 2.19$ & 17 & $0.19 \pm 0.06$ & 17 & $0.17 \pm 0.05$ & 25 & $0.30 \pm 0.08$ & 14 \\
\hline 300 & $4.66 \pm 2.22$ & 25 & $0.31 \pm 0.26$ & 16 & $0.21 \pm 0.07$ & 19 & $0.38 \pm 0.08$ & 5 \\
\hline 320 & $6.34 \pm 2.67$ & 35 & $1.12 \pm 0.90$ & 9 & $0.21 \pm 0.06$ & 25 & - & - \\
\hline 340 & $7.25 \pm 2.50$ & 33 & $1.53 \pm 1.76$ & 6 & $0.20 \pm 0.07$ & 22 & $0.19 \pm 0.02$ & 2 \\
\hline 360 & $8.33 \pm 2.53$ & 16 & $5.63 \pm 3.91$ & 6 & $0.21 \pm 0.10$ & 23 & & \\
\hline 380 & $7.58 \pm 3.89$ & 6 & $1.29 \pm 1.14$ & 2 & $0.16 \pm 0.05$ & 12 & & \\
\hline 400 & $7.72 \pm 2.74$ & 11 & $2.14 \pm 1.51$ & 4 & $0.29 \pm 0.09$ & 5 & & \\
\hline 420 & $6.94 \pm 3.61$ & 7 & $3.67 \pm 2.91$ & 3 & 0.27 & 1 & & \\
\hline 440 & $10.3 \pm 1.3$ & 3 & $2.13 \pm 2.03$ & 2 & & & & \\
\hline 460 & - & & $9.02 \pm 2.91$ & 2 & & & & \\
\hline
\end{tabular}
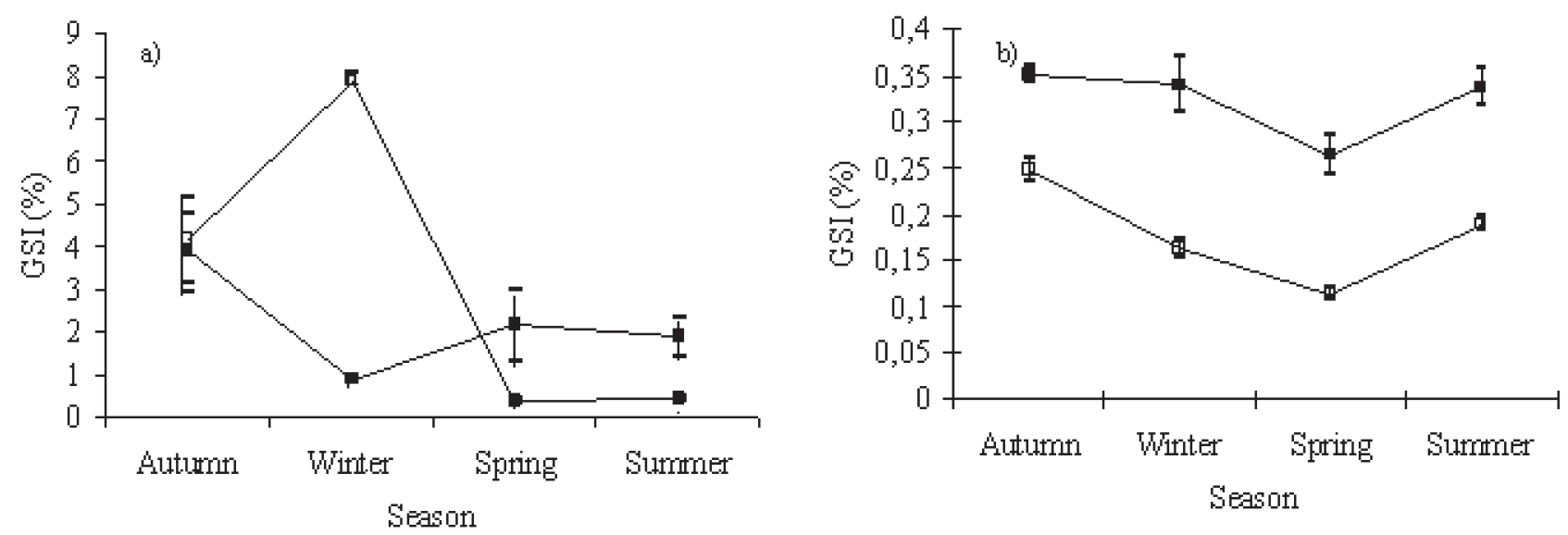

FIG. 4. - Seasonal variation of mean ( \pm S.E) gonadosomatic index (GSI) in females (a) and males (b) of T. torpedo ( $\square$ ) and T. marmorata (

much shorter ranges of variation (between 0.16 and $0.29 \%$ in T. torpedo and between 0.19 and $0.38 \%$ in T. marmorata).

T. torpedo females showed significant differences in GSI among seasons (ANOVA, d.f.=3 and 219, $\mathrm{P}<0.001$ ), with autumn and winter mean GSI values (Fig. 4a) higher than spring and summer ones (LSD test, winter $>$ autumn $>$ summer $=$ spring, $\mathrm{P}<0.05)$. Also, in T. marmorata females significant differences were found in mean GSI among seasons (ANOVA, d.f. $=3$ and 68, $\mathrm{P}<0.05$ ), with the index decreasing sharply between autumn and winter (Fig. 4a), then increasing slightly and attaining similar values in spring and summer (LSD test, autumn $\geq$ spring=summer=winter, $\mathrm{P}<0.05$ ). For $T$. torpedo males (ANOVA, d.f. $=3$ and 181, $\mathrm{P}<0.001$ ), the index decreased from autumn to spring (Fig. 4b), then increased in summer (LSD test, autumn $>$ sum- mer=winter $>$ spring, $\mathrm{P}<0.05)$; in males of $T$. marmorata (ANOVA, d.f. $=3$ and $90, \mathrm{P}<0.01$ ) only the GSI mean values in spring were different from those of the other seasons (Fig. 4b) (LSD test, autumn=winter=summer $>$ spring, $P<0.05)$. The monthly evolution of maturity stages in adult females of T. torpedo (Fig. 5) showed that all the sampled specimens were mature from November to March and early pregnant from the end of March to the beginning of July. In July and August, almost all the examined specimens were late pregnant; in September and October about $80 \%$ of the sample were post-pregnant and 20\% mature. Mean values of MOD increased from November to March, then decreased sharply from April to August before starting to increase again in September (Fig. 5).

The bi-monthly percentage of maturity stages in adult females of T. marmorata (Fig. 6) indicat- 


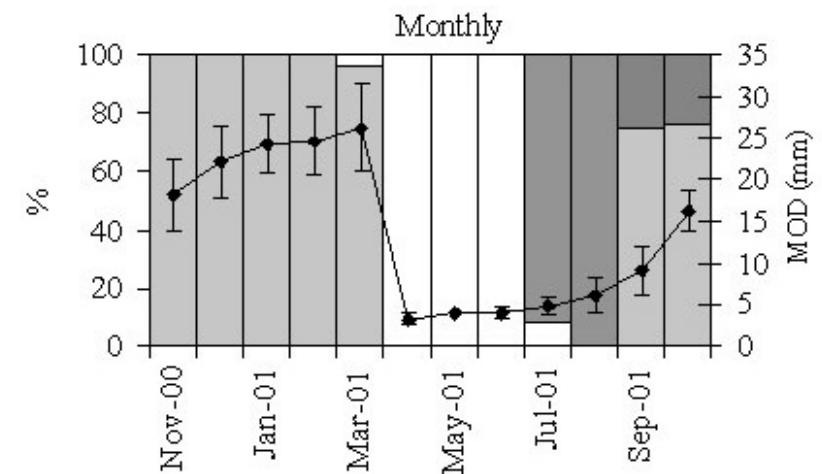

FIG . 5. - Monthly evolution of maturity stages in adult females of T. torpedo ( $\square$ mature; $\square$ early pregnant; $\square$ late pregnant; $\square$ postpregnant) and monthly variation of mean $( \pm$ S.D.) maximun oocyte diameter (MOD) in adult females of T. torpedo.

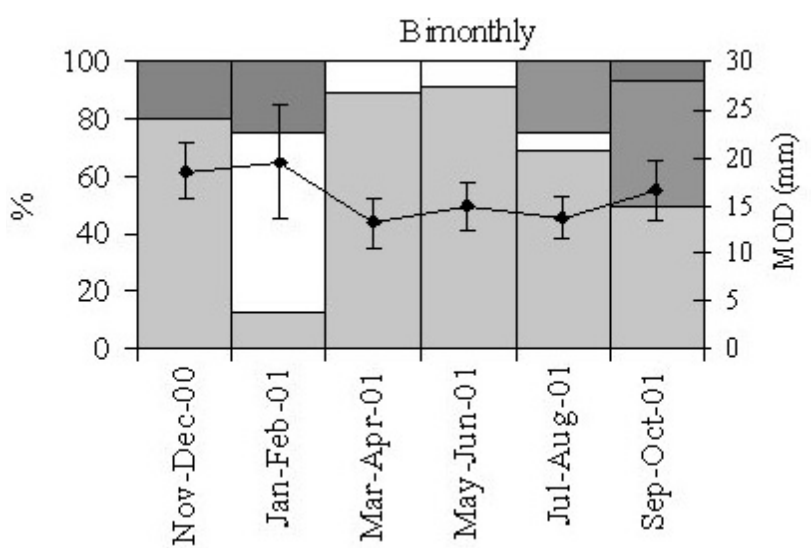

FIG . 6. - Bi-monthly evolution of maturity stages in adult females of T. marmorata ( $\square$ mature; $\square$ early pregnant; late pregnant; post-pregnant) and bi-monthly mean ( \pm S.D.) maximum oocyte diameter (MOD) in adult females of T. marmorata.

ed that mature individuals were found all year round. Early pregnant specimens were found from January (the greatest amount) to August, whereas late pregnant individuals occurred from July to October and post-pregnant ones from September to February. Mean values of MOD (Fig. 6) were higher in the autumn-winter season than in the spring-summer one.

The analysis of 187 mature females of T. torpedo (235-477 $\mathrm{mm} \mathrm{TL})$ in full vitellogenic activity revealed 2 to 22 yellow-yolked ovarian eggs. Counts of embryos in uteri of 26 pregnant females revealed a range from 4 to 19 . The 57 mature $T$. marmorata females (267-492 $\mathrm{mm}$ TL) contained 1 to 35 mature ovarian eggs. Embryos, found in uteri of 18 pregnant females, ranged from 3 to 16 . Ovarian and uterine fecundity increased significantly with length in both $T$. torpedo (ovarian: FTest, d.f. $=1$ and 185, $\mathrm{P}<0.001$; uterine: F-Test, d.f. $=1$ and $24, \mathrm{P}<0.001$ ) and T. marmorata (ovarian: F-Test, d.f. $=1$ and 44, $\mathrm{P}<0.001$; uterine: F-Test, d.f. $=1$ and 16, $\mathrm{P}<0.01)$. Slopes of the TL-ovarian fecundity relationship between the two species (Fig. 7) were significantly higher in $T$. torpedo than in T. marmorata (Student's t-test for homogeneity of slope: d.f. $=229, \mathrm{P}<0.001)$; otherwise, comparing uterine fecundity (Fig. 8) slopes were not significantly different (Student's t-test for homogeneity of slope: d.f. $=40, \mathrm{P}>0.5)$. Mean uterine fecundity was further compared, resulting higher (t-test: d.f. $=41, \mathrm{P}<0.001)$ in T. torpedo $(9.5$ \pm 1.4 S.D.) than in T. marmorata $(7.9 \pm 3.9$ S.D $)$.

The embryo mean TL of T. torpedo was respectively $47.4 \mathrm{~mm}$ in July and $63.8 \mathrm{~mm}$ in August. The largest embryo measured $80.0 \mathrm{~mm}$ TL and the smallest free-swimming specimen measured 96.0 mm TL. The embryo mean TL of T. marmorata was $48.3 \mathrm{~mm}$ in July, $96.0 \mathrm{~mm}$ in September and $109.7 \mathrm{~mm}$ in October; the largest embryo found measured $117.0 \mathrm{~mm} \mathrm{TL}$, and the smallest freeswimming specimen measured $100.0 \mathrm{~mm}$ TL. Length-weight relationships in embryos of $T$. torpedo and T. marmorata (Fig. 9) were both significant (F-test, d.f. $=1$ and 179, $\mathrm{P}<0.001$; F-test, d.f.= $81, \mathrm{P}<0.001$, respectively) and showed a negative (t-test: d.f. $=362, \mathrm{P}<0.001)$ and a positive $(\mathrm{t}$-test:

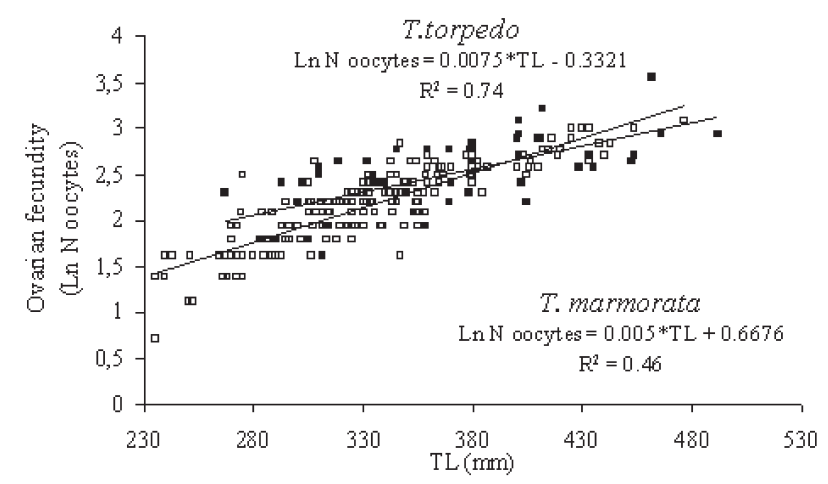

FIG . 7. - Relationship between ovarian fecundity and total length in T. torpedo $(\square)$ and T. marmorata $(\square)$

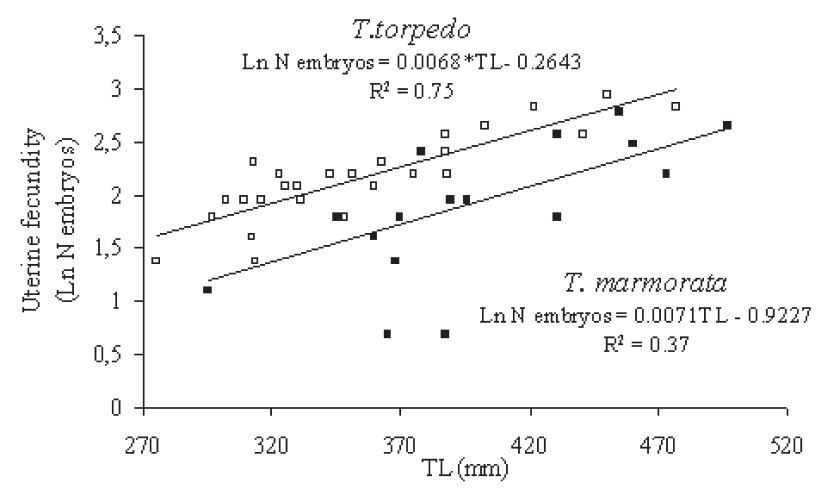

FIG . 8. - Relationship between uterine fecundity and total length in T. torpedo $(\square)$ and T. marmorata $(\square)$. 

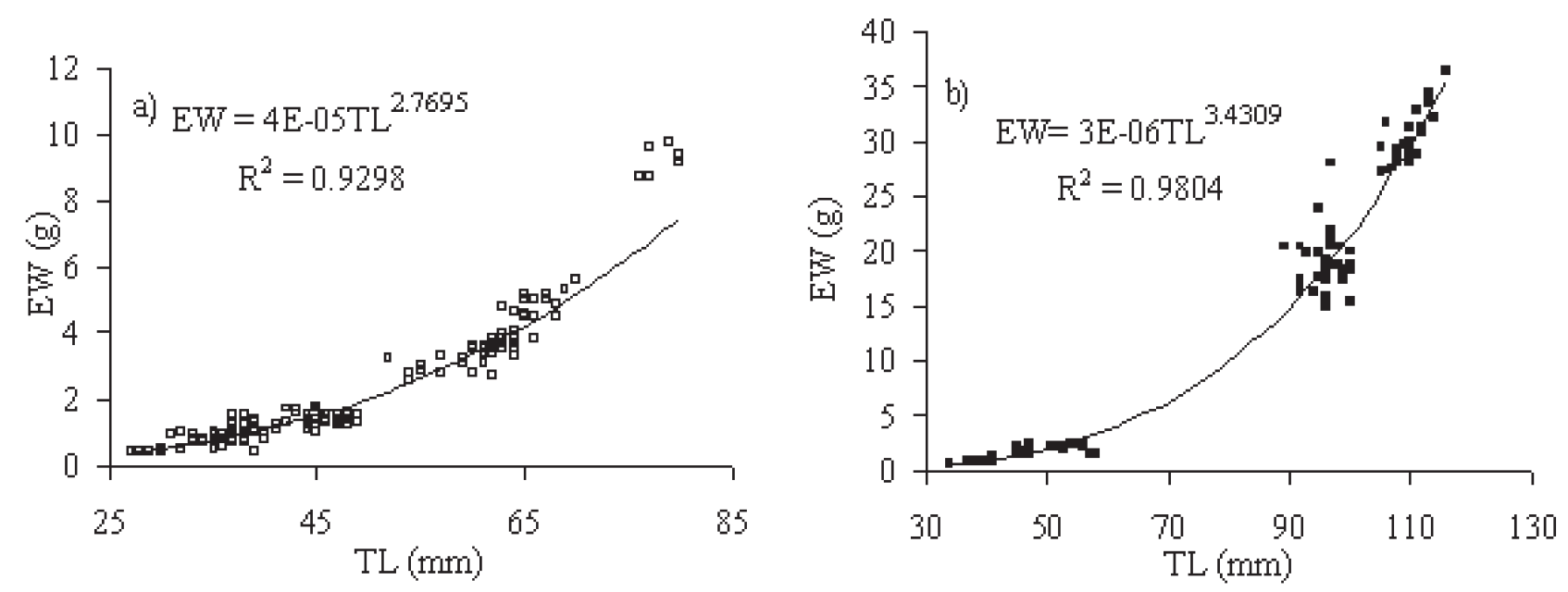

FIG . 9. - Relationship between eviscerated weight and total length in embryos of T. torpedo (a) and T. marmorata (b).

d.f.= 165, P<0.001) allometry, respectively. The allometric coefficient was higher in embryos of $T$. marmorata than in those of T. torpedo (Student's ttest for homogenity of slope: d.f $=260, \mathrm{P}<0.001)$.

\section{DISCUSSION}

The males and females of $T$. torpedo analysed in this work attained larger sizes (TL $15 \mathrm{~cm}$ greater for males and 6-11 cm greater for females) than in other Mediterranean areas (Capapè, 1979; AbdelAziz, 1994; Ennajar et al., 2002; Capapè et al., 2004 ). However, females of this species attained smaller sizes (TL $8 \mathrm{~cm}$ less) than those in Atlantic populations (Capapè et al., 2000). On the other hand, T. marmorata males and females showed no evident differences in maximum length compared to the same areas.

Some interesting results were achieved in comparison between sexes of the two investigated species: taking into account the effect of size, males of $T$. torpedo attained a greater mean mass than those of T. marmorata, and vice versa for females. This result was not in accordance with observations within the Mediterranean and Atlantic populations, where both sexes of T. marmorata were always bigger than T. torpedo (Capapè et al. 2004). Such observed interspecific differences between males could be explained on the basis of two hypotheses:

1) geographic related changes in size are common in elasmobranchs, as reported by some authors (Faurè-Fremiet, 1942; Moreno, 1995) and they are related to environmental influences, especially food availability, light, temperature and other (Leloup and Oliverau, 1951). The availability of organic and inorganic nutrients in the sampling area is chiefly related to the surplus produced by the contribution of the Tiber river flow in coastal Latium waters (Ardizzone et al., 1985), which are preferred by the common torpedo. A very likely positive cascade effect on coastal food web biomass should be reflected in an increase in size in the common torpedo population of Latium inshore waters. As mentioned above, our samples of common torpedo were larger in size than those in other Mediterranean areas but smaller than those in the Atlantic. Owing to the mesotrophic condition usually found in oceanic environments (Barnes and Hughes, 1982), some fish species attain larger size in the Atlantic than in the Mediterranean (Froese and Pauly, 2006), which is a typical oligotrophic environment (Ghirardelli, 1981). The observed difference between males was due to a truly geographic-related increase in size affecting common the torpedo population of Latium inshore waters. Therefore, such a hypothesis is consistent.

2) Sexual segregation. It is known that in elasmobranchs sexes tend to segregate by depth and/or by area, with males distributed at deeper stands in relation to reproduction (Sims, 2005). In the study area, $95 \%$ of Fiumicino landing comes from coastal bottom trawlers operating on bottoms of the continental shelf and slope (Sbrana et al., 2000). Hence, sampling effort was adequate to cover the entire known distribution of both species (0-300 m depth; Froese and Pauli, 2006). Furthermore, it is unlikely that the sampling effort excluded larger males of the marbled torpedo because the maximum total length observed in this 
sample was similar to that recorded in other Mediterranenan areas (Ennajar et al., 2002; Capape et al., 2004). Therefore such a hypothesis is not consistent.

Some differences in population structure between the two species studied can be inferred from frequency distributions. Although genders were equally represented at birth in both species, in the $T$. torpedo population sexes exhibited a similar size range, as Abdel-Aziz (1994) also observed. On the other hand, T. marmorata females attained very large sizes compared to males and became predominant in number as size increased. Furthermore, females of both species exhibited a higher rate of mass increment with size than males, as Mellinger (1971) and Capapè (1979) observed previously. These results agree with the observations of Mellinger (1989) that in elasmobranch viviparous species larger females are of particular value in carrying the brood during the whole gestation, providing organic and inorganic nutrients (Capapè et al., 2004). Hence, the larger increase in female size observed in T. marmorata than in T. torpedo indicated that the former need a greater energy requirement for gestation (i.e. longer duration) than the latter. This observation was based on size at first maturity, which was similar in males and females of $T$. torpedo but different in T. marmorata, with males reaching maturity at a smaller size than females, as also observed by Mellinger (1971), Capapè (1979) and Abdel-Aziz (1994). Since a reduction in growth rate is expected after size at first maturity is attained, the delay in female maturation in comparison with males is related to the numerical predominance of females within the largest size classes (Cortes, 2000). Since larger females exhibit a greater fecundity, this represents an evolutive advantage for elasmobranchs (Cortes, 2000). Also in this work, both species showed an increase in fecundity with size, as several authors have reported in the Mediterranean and Atlantic (Ranzi, 1932; Tortonese, 1956; Mellinger, 1971; Quignard and Capapè, 1974; Abdel-Aziz 1994). Ovarian and uterine fecundity were similar in $T$. torpedo, indicating that all ripe oocytes were fertilised. In T. marmorata, ovarian fecundity was higher than uterine fecundity, indicating that either some ripe oocytes were not ovulated but degenerated, or a bias exists due to the behaviour of pregnant females which lose their brood when they are caught, as Lo Bianco observed (1888). Comparing the two species, both the ovari- an and the uterine fecundity of T. torpedo were higher than those of T. marmorata, indicating that T. torpedo is likely to exhibit a greater reproductive potential than T. marmorata.

T. torpedo size at birth was smaller than that of $T$. marmorata, and their embryos were similar in size to those in other geographical Mediterranean areas (Ranzi, 1932; Quignard and Capapè, 1974; AbdelAziz; 1994). Furthermore, the comparison between allometric coefficients indicated that size difference in post-partum populations between the two species already started at the embryonic development stage.

According to seasonal and monthly variation of GSI and MOD, ovulation in T. torpedo was assumed to take place between late winter and early spring, as also observed by Ranzi (1932) and Quignard e Capapè (1974) on Tunisian coasts. The gestation period was assumed to last about six months and parturition probably took place from late August to early September, as also observed in North African populations (Quignard and Capapè, 1974; Abdel Aziz, 1994). Consequently, the common torpedo was confirmed to have an annual reproductive cycle also in the central Mediterranean Sea. Seasonal evaluation of male GSI suggested that mating occurred between autumn and winter.

The reproductive cycle of $T$. marmorata probably lasts two years at least (Lo Bianco, 1909; Ranzi, 1932; Uva and Tagliaferro, 1968; Mellinger $1971 ; 1974)$. Seasonal and bi-monthly variation in GSI and MOD did not clear the sexual cycle of mature females of $T$. marmorata because of the presence of different categories of mature females during the same period of the year. Mature females, ready for ovulation, were observed mostly in autumn, whereas early pregnant ones with uterine eggs were observed in January and February. The disappearance of pregnant females in November and December suggested that gestation could last 9-10 months, as Mellinger (1974) observed in the Gulf of Guascogne, and hatching could occur in late October. The GSI seasonal variation in males indicated that mating was likely to occur between autumn and winter.

In conclusion, although T. torpedo and T. marmorata are both strictly k-selected species, as viviparous aplacental breeders, some distinctive differences can be pointed out. T. torpedo, more abundant in coastal waters (Tortonese, 1956; Bini, 1967), was a more fecund species with both a less pronounced size dimorphism and a numerical equi- 
librium between sexes. Such features, together with an annual reproductive cycle, lead to an enhanced mating likelihood and an optimised reproduction success in coastal areas, where variability of environmental factors is more intense. Conversely $T$. marmorata, inhabiting a deeper environment (Fischer et al., 1987), proved to be a less fecund species with a distinct size dimorphism and with a numerical predominance of females within the largest size classes. These aspects, together with the suspected two-year reproductive cycle, can be put down to the obtaining of a better newborn survivorship. In other words, the common and the marbled torpedo display a different degree of k-strategy, the former adapted to a more fluctuating environment and the latter typical for steady environment conditions.

\section{ACKNOWLEDGEMENTS}

The authors wish to thank E. Gennari, S. Agnesi and A. Sarni for their help in this work. We also thank the anonymous referee for improving the manuscript.

\section{REFERENCES}

Abdel-Aziz, S.H. - 1994. Observations on the biology of the common Torpedo (Torpedo torpedo, Linnaeus, 1758) and marbled electric Ray (Torpedo marmorata, Risso, 1810) from Egyptian Mediterranean waters. Aust. J. Mar. Fresh. Res., 45: 693-704.

Aldebert, Y. - 1997. Demersal resources of the Gulf of Lions (NW Mediterranean). Impact of exploitation on fish diversity. Vie Milieu, 47: 275-284.

Ardizzone, G.D., A. Belluscio, P. Schintu., F. Gravina, R. Maj, F. Scaletta and R. Coen. - 1985. Risultati preliminari delle campagne di pesca svolte dall'U. O. n.6 (zona Torvajanica-Foce del Garigliano) In: Atti Seminari M.M.M.-C.N.R. unità operative promossi nell'ambito dello schema preliminare di piano per la pesca e acquacoltura, pp. 1239-1269. Ministero Marina Mercantile, Roma.

Barnes, R.S.H. and R.N. Hughes. - 1982. An introduction to marine ecology. Blakwell scientific, Oxford.

Bass, A.J., J.D.D’Aubrey and N. Kistnasamy. - 1973. Sharks of the east coast of southern Africa. 1. The genus Carcharhinus (Carcharhinidae). Oceanographic Research Institute (Durban) Internal Report No. 33.

Bertrand, J., L. Gil De Sola, C. Papacostantinou, C. Relini and A. Souplet. - 2000. Contribution on the distribution of elasmobranchs in the Mediterranean (from Medits surveys). Biol. Mar. Mediterr., 7: 385-399.

Bigelow, H.B. and W.C. Schroeder. - 1953. Fishes of the western North Atlantic, Part 2. In: J. Tee-Van, C.M. Breder, S.F. Hildebrand, A.E. Parr and W.C. Schroeder (eds.). Sawfishes, guitarfishes, skates, rays, and chimaeroids. Yale University, New Haven.

Bini, G. - 1967. Atlante dei pesci delle coste italiane, 1, Leptocardi, Ciclostomi, Selaci. Mondo Sommerso, Milano.

Capapé, C. - 1979. La torpille marbrée, Torpedo marmorata Risso, 1810 (Pisces, Rajiformes) des côtes tunisiennes: nou- velles données sur l'écologie et la biologie de la reproduction de l'espèce, avec une comparaison entre les populations méditerranéennes et atlantiques. Annal. Sci. Nat., Zoologie, Paris, 13: 79-97.

Capapè, C., A.A. Seck, and Y. Diatta. - 2000. Reproductive biology of the common torpedo, Torpedo torpedo (Linnaeus, 1758) (Pisces, Torpedinidae) from the coast of Senegal (Eastern Tropical Atlantic). Miscelània Zool., 23: 9-21.

Capapé, C., J.P. Quignard and O. Guélorget. - 2004. Observations on biometrical parameters in elasmobranch species from Maghrebin waters: a survey. Annales Ser. Hist. nat., 14: 1-10.

Chieffi, G. - 1961. La luteogenesi nei Selaci ovovivipari. Ricerche istologiche e istochimiche in Torpedo mormorata e Torpedo ocellata. Pubbl. Staz. Zool. Napoli, 32:145-166.

Cortes, E. - 2000. Life history patterns and correlations in sharks. Rew. Fish. Sci. 8: 299-344.

Ennajar, S., M.N. Bradaï and A. Bouaïn. - 2002. La reproduction de la torpille ocellée Torpedo torpedo (Linnaeus, 1758) du Golfe de Gabès. Bull. Inst. Natn. sci. Techn. Océanogr. Péche, Salammbo, $29: 40-43$.

Fauré-Frémiet, E. - 1942. Notes sur la biologie sexuelle de Scylliorhinus canicula. Bull. biologique., 76: 244-249.

Fischer, W., M.L. Bauchot and M. Schneider. - 1987. Fiches Fao d'identification des espèces pour le besoins de la peche. Méditerranée et Mer Noire (Rev. 1). FAO, Rome.

Fisher, R.A. - 1922. On the interpretation of Chi-square from contingency tables, and the calculation of p. J. R. Stat. Soc., 85: 87-94.

Fletcher, R. and C.M Reeves. - 1964. Function minimization by conjugate gradients. Comput. J., 7: 149-154.

Froese, R. and D. Pauly. - 2006. FishBase. World Wide Web electronic publication.www.fishbase.org, version (06/2006). Froese, R. and D. Pauly Eds.

Ghirardelli, E. - 1981. La vita nelle acque. UTET, Torino.

Hemida, F., F. Moumene and D. Giordano. - 2000. Distribution of some ray species from the Algerian basin. Biol. Mar. Mediterr., 7: 412-416.

Hooke, R., and T.A. Jeeves. - 1961. Direct search solution of numerical and statistical problems. J. Assoc. Comput. Mach. 8:212-229

Leloup, J. and M. Oliverau. - 1951. Données biométriques comparatives sur la Rossette (Scyllium canicula L.) de la Manche et de la Méditerranée. Vie Milieu, 2: 182-206.

Lo Bianco, S. - 1888. Notizie biologiche riguardanti specialmente il periodo di maturità sessuale degli animali del Golfo di Napoli. Mitt. Zool. Stn. Neapel, 8: 385-440.

Lo Bianco, S. - 1909. Notizie biologiche riguardanti specialmente il periodo di maturità sessuale degli animali del Golfo di Napoli. Mitt. Zool. Stn. Neapel, 19: 513-761.

Mellinger, J. - 1971. Croissance et reproduction de la torpille (Torpedo marmorata). I. Introduction écologie, croissance générale et dimorphisme sexuel, cycle, fécondité. Bull. Biol. Fr. Belgique, 105: 165-218.

Mellinger, J. - 1974. Croissance et reproduction de la torpille (Torpedo marmorata). III. L'appareil génital femelle. Bull. Biol. Fr. Belgique, 108: 107-150

Mellinger, J. - 1989. Reproduction et développement des Chondrichthyens. Océanis, 15: 283-303.

Moreno, J.M. - 1995. Guida de los Tiburones de Aguas ibèricas, Atlantico Nororiental y Mediterraneo. Ediciones Piramide, Madrid.

Quignard, J.P. and C. Capapé. - 1974. Recherches sur la biologie d'un sélacien du golfe de Tunis, Torpedo torpedo Linné, 1758. Bull. Inst. Natn. Sci. Tech Océanogr. Péche Salammbò, 3: 99-129.

Quignard, J.P. and J.P.Tommasini. - 2000. Mediterranean fish biodiversity. Biol. Mar. Mediterr., 7:1-66.

Ranzi, S. - 1932. Le basi fisio-morfologiche dello sviluppo embrionale dei selaci. Parte I. Pubbl. Staz. Zool. Napoli, 12:209-290.

Sbrana, M., G.D. Ardizzone, P. Belcari, A. Belluscio, P. Gentiloni, B. Reale and P. Sartor. - 2000. Monitoring of the trawl and gillnet landings in the Central and Northern Tyrrhenian Sea. Report of EU study contract $\mathrm{N}^{\circ} 97 / 0068$.

Serena, F. - 2005. Field identification guide to the sharks and rays of the Mediterranean and Black Sea. FAO, Rome.

Sims, D.W. - 2005. Differences in habitat selection and reproductive strategies on male and female sharks. In: K. Ruckstuhl and 
P. Neuhus (eds.). Sexual Segregation in Vertebrates: ecology of the two sexes. Cambridge University Press, Cambridge.

Soldo, A. - 2003. Status of sharks in the Mediterranean. Annales Ser. Hist. Nat., 13: 191-200.

Stehmann, M. and D.L. Bürkel. - 1984. Torpedinidae. In: P.J.P. Whitehead, M.L.Bauchot, J.C. Hureau, J. Nielsen and E. Tortonese (eds.), Fishes of the North-eastern Atlantic and the Mediterranean, pp 156-158. UNESCO, Paris

Stehmann, M. - 2002. Proposal of a maturity stage scale for oviparous and viviparous cartilaginous fishes (Pisces, Chondrichthyes). Arch. Fish. Mar. Res., 50: 23-48.

Tortonese, E. - 1956. Fauna d'Italia. Leptocardia, Ciclostomata, Selachii. Calderoni, Bologna.

Uva, B. - 1971. Osservazioni sulla mucosa uterina di Torpedo marmorata Risso durante il ciclo di attività gustativa. Boll. Mus. Ist. Biol. Univ. Genova, 39: 83-101.
Uva, B. and G. Tagliaferro. - 1968. Istomorfologia dell'ovidutto di Torpedo marmorata e Torpedo ocellata durante il ciclo di attività gustativa. Boll. Mus. Ist. Biol. Univ. Genova, 36: 67-126.

Vacchi, M. and G. Notarbartolo Di Sciara. - 2000. I pesci cartilaginei dei mari italiani, una risorsa che richiede urgenti misure di tutela. Biol. Mar. Mediterr., 7: 296-311.

Walker, P.A. and J.R.G. Hyslop. - 1998. The biology of the skates Raja wallacei and Raja pullopunctata (Batoidea: Rajidae) on the Agulhas Bank, South Africa. S. Afr. J. Marine Sci., 21: 165-179.

Zar, J.H. - 1996. Biostatistical Analysis, $3^{\text {rd }}$ Edn., Prentice-Hall, Englewood Cliffs.

Scient. ed.: M.P. Olivar.

Received May 31, 2006. Accepted January 2, 2007.

Publisher online May 17, 2007. 